\title{
Strategies for Effective Use of TVET Advocacy in Promoting Gender Equity of Students in TVET Institutions in Uganda: Multiple Informants Perceptions
}

\author{
Aidah T. Nganda ${ }^{1}$, Dr. Salome Nyambura ${ }^{2}$, Dr. Francis Kirimi ${ }^{3}$ \\ ${ }^{I}$ Doctoral student, Department of Educational Foundations, Kenyatta University, Nairobi, Kenya \\ ${ }^{2,3}$ Lecturers, Department of Educational Foundations, Kenyatta University, Nairobi, Kenya
}

\begin{abstract}
This study explored strategies for effective use of TVET advocacy in the promotion of gender equity of TVET students in the Central Region, Uganda. Thus, a convergentparallel mixed methods research design, with a survey strategy was adopted, to achieve the objectives. Two theories including the feminist socialization theory and subject-task value theories guided the conceptualization of this study. The study targeted 5,791 students, 240 instructors, 60 institutional leaders, 42 district leaders, 4 Ministry of Education and Ministry of Gender Labour and Social Development officials, and 21 civil society organisation gender advocates. Purposive sampling was used to select 9 institutional leaders, 3 district leaders, and 2 ministry officials while convenience sampling was used to select 5 gender advocates. Likewise, stratified random sampling was used to select 185 students and 56 instructors. Therefore, a sample size of 260 informants was used. Questionnaires, interview guides, and observation checklists were used to collect the desired data. The quantitative data was cleaned, coded, and entered into Statistical Package for Social Sciences software version 21 for analysis. Frequencies, percentages, means, standard deviations, and bar graphs were used to present the analysed data. Qualitative data was analysed using the thematic method and presented using verbatim and indirect reporting. The findings revealed a lowstatus quo for TVET, moderate use of different TVET advocacy strategies, and affirmed that effective use of TVET advocacy enhanced gender equity of students in Uganda. The study recommended that TVET institutions effectively implement different advocacy strategies, the Uganda government to employ experts for TVET advocacy and increase the budget for supporting the implementation of different advocacy strategies.
\end{abstract}

Keywords: Strategies, TVET Advocacy, Effective use, Gender Equity, TVET institutions

\section{INTRODUCTION}

$\mathrm{G}$ ender equity in education has been a fundamental J concern at global and national levels. In our study, gender equity denotes fairness in students' enrolment, participation, and allocation of resources in selected TVET programs. Multiple strategies and policies have been enacted to attain equity and promote inclusive TVET. Globally, the UN established the United Nations Girls' Education Initiative (UNGEI), which encouraged its state parties to use appropriate measures like equitable career and vocational guidance to promote gender equity (UNGEI, 2012).

Additionally, goal 4 of the 2030 Agenda for sustainable economies stresses the requisite for inclusive and equitable education, including Technical, Vocational Education, and Training (TVET) for all nations and genders (UNESCO, 2016a). Despite these efforts, an evaluation of the 2010-2015 strategy for TVET showed that 73 million youths are unemployed, regardless of 40 million annual TVET enrolments worldwide. Consequently, many people particularly women lack opportunities for skills development and decent work. In 2014 for example, the global unemployment rate for women and men was $6.4 \%$ and $5.7 \%$ respectively (UNESCO, 2016b), which hampers development and gender equity.

Specifically, studies about the global TVET trends (Wheelahan \& Moddie, 2016) showed that enrolment and participation in post-secondary TVET for Sub-Saharan Africa (SSA) and South Asia averaged at 3 million students compared to 30 million and 18 million in Eastern Asia and Europe respectively. Likewise, the 2020 global gender gap report revealed that few developing are yet to close the $20 \%$ gap in educational attainment, with ten percent of girls aged 15-24 in the world being illiterate (World Economic Forum (WEF), 2019).

Kell (2010) in Switzerland noted that VET's response to promoting equity had loosened, where oppressive approaches continued to hamper equity and social justice in TVET. Moreover, several contradictions were noted in policies designed to promote participation, and challenges of students and instructors remained unsettled, thus stalling advocacy for TVET.

In United Kingdom (UK), Atkins \& Flint (2015) identified multiple contributors to students' TVET choices including previous grades, future career goals, career guidance, peer and familial influence. They noted that policies could boost higher TVET participation, but might not enhance TVET advocacy for mid-level TVET. 
In Kenya, statistics by the Ministry of Education, Science and Technology (MoEST) showed an increase in female students' enrolment in public Technical, Industrial Vocational and Entrepreneurship Training (TIVET) from 40,622 in 1999 to 65,500 in 2004 (Mugenda, Kimani, Maina, \& Wainaina, 2010).

Conversely, most females were enrolled in gender-biased trades like home science and few in technical courses like carpentry. More so, TVET's historic masculine perception continues to influence the participation of females in the field (Sifuna \& Chege, 2006, in Mbirianjau, 2009). This vocational fallacy has thus persisted, where females are encouraged to participate in 'soft' TVET courses which have a lower remuneration than the 'hard' technical courses (Mbirianjau, 2009), resulting in gender inequities in training and the labour market.

Worse still, inadequate funding for activities intended for the promotion of gender equity, limited gender awareness among students, staff, and institution managers, unclear gender policy guidelines, as well as negative attitudes towards gender issues continue to impede sustainable gender equity interventions (Cheruiyot \& Wanyaga, 2019).

In Nigeria, Adelakun, Oviawe, \& Barfa (2015) interestingly cited advocacy by government and policymakers, multi-level government sensitization, career guidance, counselling, and enactment of policies that enhance equitable participation, as strategies for promoting gender equity in TVET. The contribution of these advocacy strategies towards the promotion of gender equity in TVET is limitedly known.

In Uganda, chapter 4 and clause 30 of her Constitution stresses the need for equitable access to education opportunities without any form of discrimination (the Republic of Uganda, 1995). Therefore, several policies were developed at different education levels. Specific to TVET are the Business Technical Vocational Education and Training (BTVET) act of 2008, modified into the BTVET strategic plan (Ministry of Education and Sports (MoES), 2011), and the National Strategy for Girls Education (NSGE) in Uganda (MoES, 2013). Despite the enactment of such policies and strategies, statistics from the Uganda Bureau of Statistics $(\mathrm{UBoS})$ revealed enrolment of more than fifty percent males than females in tertiary institutions, partly due to females' low grades at lower education levels, familial and societal reasons (UBoS, 2012, 2016). Likewise, female students' enrolment was low in technical and agricultural courses, and higher in health and home sciences, due to gender stereotypes in the different vocational trades (Okello, 2012; UBOS, 2016). The contribution of such vocational fallacies and attitudes to the promotion of gender equity in TVET is limitedly known in Uganda. Whereas policies to enhance access to and participation in TVET exist, impediments to their dissemination, implementation, and evaluation continue to hamper their proper use in the promotion of gender equity. Additionally, advocacy for strategies designed to promote gender equity in TVET is still limited, with homogeneous policy interventions for rural and urban settings, despite conditions for and against policy dissemination and implementation in the two contexts. Consequently, TVET enrolment and participation in Uganda have remained low, with inadequate systematic data for different TVET programs. This study thus sought to explore strategies for effective use of TVET advocacy in promoting gender equity of students in TVET institutions in Uganda.

\subsection{Purpose of the study}

To explore strategies for effective use of TVET advocacy in promoting gender equity of students in TVET institutions in Uganda

\subsection{Specific Objectives}

The specific objectives were to:

i. Explore the current students' enrolment in TVET institutions in Uganda.

ii. Establish informants' knowledge for TVET policies that promote gender equity of TVET students in Uganda.

iii. Explore the extent to which different advocacy strategies were used to promote gender equity of TVET students in Uganda

iv. Establish informants' perceptions about how different advocacy strategies enhance gender equity of students in Uganda

\section{LITERATURE REVIEW}

\section{$2.1 \quad$ Theoretical Review}

This study was guided by conceptualisations of two theoriesthe Feminist Socialisation Theory (FST) in education (Thompson, 2003) and the Subject-Task-Value (STV) theory (Eccles, 2005). The FST demands equal treatment of men and women, using its liberal approach to solving problems like gender inequities. Thus, the feminist socialisation theorists opined the use of rational educational programs and corrective affirmative policies (Thompson, 2003). Relating to our study, TVET was the liberal dimension through which gender inequities can be addressed using TVET advocacy strategies. FST also proposed strategies for promoting gender equity in education including fair treatment of males and females by teachers and parents, and school administrators... and addressing personal socialized perceptions (Thompson, 2003, p.15).

Likewise, STV theory argued that students' motivations and achievement-related choices are influenced by their expectations to succeed and subjective-task values (Eccles, 2005). Therefore, equitable participation in TVET and choice of TVET trade were influenced by one's interests and motivations and how valuable TVET was to him/her. STV underlines four value dimensions that are: attainment value, intrinsic value, utility value, and cost value. Attainment value relates to one's ability to excel while the 'utility value' denotes relevance of the choice taken. In this study, the 
attainment value was anticipated to impact institutional and individual choices of TVET trades, which also depend on grades at lower educational levels. Likewise, the 'intrinsic value' describes one's level of enjoyment while the 'cost value' recounts sacrifice in form of time, efforts, funds, and valued alternatives for advocacy strategies. Therefore, multiple stakeholders including policy developers, implementers, and beneficiaries need to appreciate the contributions of the aforementioned values to equitable participation and work collaboratively to counteract their impediments.

The use of STV theory in this study was based on its keen focus on student-related factors that contribute to gender equity in TVET like students' interests and motivations, as well as advocacy-related factors.

\subsection{Empirical Studies and Knowledge Gaps}

Studies have suggested advocacy strategies that can promote gender equity in TVET. Firstly, improving the status quo for TVET can enhance TVET advocacy. According to Wheelahan \& Moddie (2016), TVET presented a low status-quo in comparison with other tertiary academic routes. More so, it was perceived as a siding for low academic achievers and not an alternative for learners with good academic competences. Interestingly, Tilak (2003, cited in Okello, 2012) revealed that TVET enjoyed a prestigious reputation, with $75 \%$ of her secondary school's enrolment as TVET, compared to $25 \%$ who attend purely academic schools. As a result, her government accorded greater freedom to principals and teachers to update curricula and new occupational fields as a form of advocacy. Despite serendipity and contingent events influencing students' choice of Further Education (FE) in the UK, TVET policies at University Technical Colleges raised esteem for specialised and elite TVET, but not the broader middle level VET programs (Atkins \& Flint, 2015). This study was hence conducted in middle-level TVET institutions where scanty research about TVET advocacy was noted.

Likewise, the use of diversified and innovative sources of funds for TVET advocacy, political will, and information strategies are vital. As emphasized by Atari \& Mckague (2015), TVET advocacy necessitates government will, political will, and close collaborations of all stakeholders. Furthermore, access to TVET is riddled by low government

funding, which has a replica effect on teacher training, poorly equipped institutions, and inadequately trained graduates (Muthima \& Ngugi, 2017). Notably, Mjelde (2007) argued that convenient training strategies like work-based training promoted TVET advocacy. Consequently, gender inequities in TVET had gradually been raised to a parity level (Mjelde, 2007, p. 147). This study thus explored whether political and government will, community and institutional leaders as forms of TVET advocacy promoted gender equity of students.

Pirzada (2020) noted that applying UNESCO TVET strategies for gender equity and equality in training was key in promoting inclusive TVET participation in institutions. Thus, raising awareness about gender issues at TVET institutes led to social benefits to students and trainees (Muthima \& Ngugi, 2017). Whereas Gore, et al., (2017) cited that male students were more likely to aspire for VET than females in Australia, Adelakun, et al., (2015) encouraged sensitization by government, policymakers, and other stakeholders at all levels about the benefits of equitable participation in TVET. These studies did not indicate whether the use of these advocacy strategies could promote gender equity of TVET students.

According to Sullivan (2019), posters were media for advocacy, voicing support, raising awareness, and communicating unfolding injustices. Resnick (2013) in her 'graphic advocacy' exhibition also affirmed posters as media for social change (ibid). Likewise, Olelewe, Orji, Onisen, \& Ikemelu (2019) noted that social networking sites (SNSs) promoted collaborative learning and participation in TVET. These studies however did not explore how the use of these advocacy strategies could promote gender equity of TVET students.

\subsection{Conceptual Framework}

The conceptual framework in figure I presents the pull and push factors for TVET advocacy as independent variables while gender equity in TVET is the dependent variable. It shows that students' grades, societies, peers, interests, families, policies, and practices influence their choice of TVET, thus contributing to gender equity. Figure I further postulates that policy interventions like the use of TVET advocacy strategies, government and political will, funding for TVET advocacy, and stakeholder collaborations could promote gender equity in TVET.

\section{METHODOLOGY}

\subsection{Research Design, Study Locale, and Target Population}

A convergent-parallel mixed methods research design was adopted in this study to explore strategies for effective use of TVET advocacy in promoting gender equity of students in TVET institutions in Uganda. This research design supported the researchers to collect and merge qualitative and quantitative data at the same time, which enabled a comprehensive analysis of the research problem (Creswell, 2014). The study was conducted in TVET institutes in the central region, Uganda. The central region was selected because of its metropolitan characteristics of urban and rural set-ups. Similarly, the TVET institutes in the central region were assumed to have conducive facilities for TVET advocacy.

The target population was 6,158 respondents including 5,791 students, 240 instructors, 60 institutional leaders, 42 District Leaders (DL), 4 MoES and Ministry of Gender Labour and Social Development (MoGLSD) officials, and 21 civil society Organisation (CSO) gender advocates. Multiple informants were involved in this study to generate diversified views about 
the various aspects being studied (Cohen, Manion, \& Morrison, 2011).

\subsection{Sampling Strategies and Sample Size}

Multiple sampling strategies were used in this study. Purposive sampling was used to select six TVET institutions from five districts in the central, region. Likewise, purposive sampling was used to select 9 institutional leaders, 2 ministry officials, and 3 district leaders. Stratified random sampling was used to select 185 students and 56 instructors basing on their TVET trades. Additionally, convenience sampling was used to select 5 gender advocates from civil society organisations (CSO) in the selected districts.

Thus, a sample size of 260 informants was used in this study.

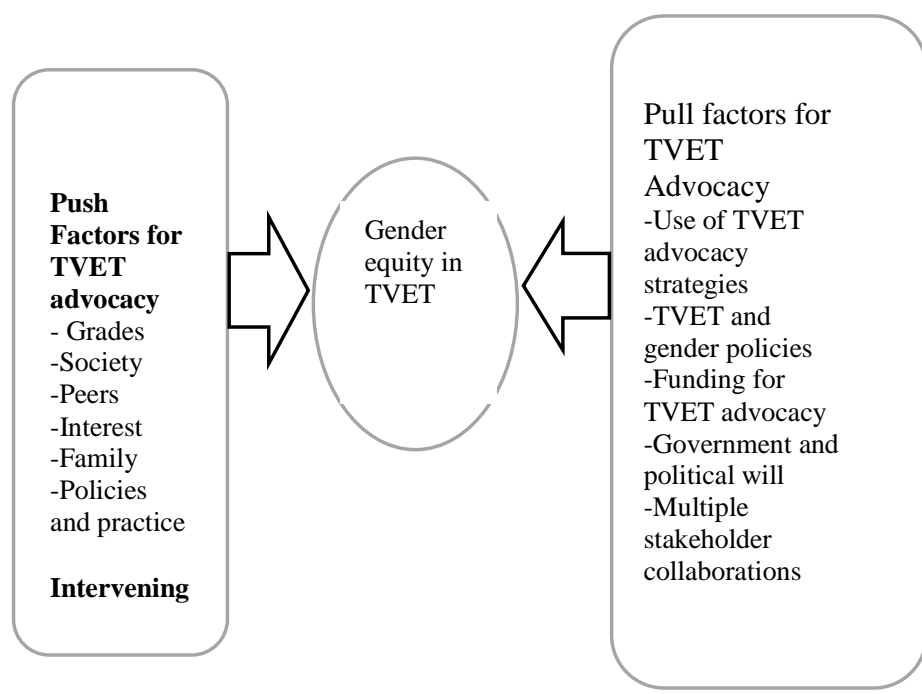

Figure 1: Conceptual Framework

\subsection{Research Instruments}

Researcher-developed tools were used to collect desired data for this study. Therefore, questionnaire guides for institutional leaders, students, and instructors were used. Similarly, interview guides for ministry officials, district officials, CSO gender advocates, role-model students, and instructors were used. Lastly, the learning environment observation checklist was used for identifying available TVET advocacy messages and gender units. With informants' permission, the researcher employed an audio-recorder to support factual transcription of interview data. The use of multiple methods provided a diversity of ideas from respondents and informants which enhanced the triangulation of data for this study.

\subsection{Pilot Study}

Piloting was done to test the content validity of research instruments and improve items, scales, and formats (Creswell, 2014). A pilot study was done for questionnaires and interview guides in two TVET institutes, one from rural and urban settings respectively. Therefore, one IL, two instructors, and three students per institute participated in the pilot study. Their responses were analysed and ambiguous items were simplified and improved in the students' questionnaire guide. Data from the 12 informants' questionnaires was entered into Statistical Package for Social Science (SPSS)-version 21 and its reliability tested using the split-half method. Thus, a Spearman-Brown prophecy value of 0.77 was obtained, showing strong reliability of study findings.

\subsection{Logistical and Ethical Considerations}

Prior to data collection, the researcher sought approval of the planned study from an ethical review committee of Mbarara University of Science and Technology (MUST). Secondly, the committee approved an informed consent form, which all informants read and signed to willingly participate in the study. Likewise, the purpose of the study was truly explained to the respondents. The principle of anonymity was employed, where no name section was included on the research tools. Instead, serial numbers and codes were used. Respondents were also assured of strict confidentiality for collected data and pseudonyms were used in reporting the findings.

Lastly, the researcher obtained administrative clearance from the Ministry of Education and Sports, participating institutions, and Uganda National Council for Science and Technology to conduct this study in TVET institutions in Uganda.

\subsection{Data Analysis and Presentation}

All research tools were physically administered by the researcher and research assistants. After collecting the qualitative and quantitative data, the researcher and the coder transcribed the data, cleaned groups, and organized data according to the study objectives. Quantitative and qualitative data from questionnaires were coded into Statistical Package for Social Science (SPSS)-version 21 for analysis. Means and standard deviations were used in the analysis of Likert-scale data about the use of different advocacy strategies while frequencies and percentages were used to present data for trade-based enrolment, familiarity with TVET policies, and biodata.

Qualitative data from interviews and observation schedules were organised into themes using the thematic analysis method. Data for different informants was triangulated to generate a diverse understanding of the subject being studied. Both verbatim and indirect reporting were used to present the qualitative findings.

\subsection{Validity and Reliability}

For descriptive and interpretive validity, face-to-face, phone debriefs and prolonged engagements were employed (Creswell, 2014). Piloting, split-half, inter-coder agreement techniques, and triangulation were used to check reliability for quantitative and qualitative data respectively. 


\section{RESULTS AND DISCUSSIONS}

\subsection{Demographic Data}

Table 1: Demographic Data of Informants

\begin{tabular}{|c|c|c|c|}
\hline $\begin{array}{c}\text { Demographic } \\
\text { categories }\end{array}$ & & $\mathrm{F}$ & $(\%)$ \\
\hline \multirow{2}{*}{ Gender $(\mathrm{N}=260)$} & Female & 106 & 40.8 \\
\hline & Male & 154 & 59.2 \\
\hline \multirow{6}{*}{ Groups $(\mathrm{N}=260)$} & Inst. Leaders & 9 & 3.5 \\
\hline & Instructors & 56 & 21.5 \\
\hline & Students & 185 & 71.2 \\
\hline & Ministry Officials & 2 & 0.8 \\
\hline & District Leaders & 3 & 1.2 \\
\hline & Gender Advocates & 5 & 1.9 \\
\hline \multirow{5}{*}{$\begin{array}{l}\text { Age in years } \\
(\mathrm{N}=250)\end{array}$} & Below 20 & 84 & 33.6 \\
\hline & $21-30$ & 107 & 42.8 \\
\hline & $31-40$ & 31 & 12.4 \\
\hline & $41-50$ & 16 & 6.4 \\
\hline & Above 50 & 12 & 4.8 \\
\hline \multirow{3}{*}{$\begin{array}{l}\text { Years of study } \\
\quad(\mathrm{N}=185)\end{array}$} & $1^{\text {st }}$ Year & 68 & 36.8 \\
\hline & $2^{\text {nd }}$ Year & 89 & 48.1 \\
\hline & $3^{\text {rd }}$ Year & 28 & 15.1 \\
\hline \multirow{4}{*}{$\begin{array}{l}\text { Working } \\
\text { experience } \\
(\mathrm{N}=65)\end{array}$} & Below 2 Years & 7 & 10.8 \\
\hline & $2-5$ Years & 19 & 29.2 \\
\hline & 6-10 Years & 20 & 30.8 \\
\hline & Above 10 Years & 19 & 29.2 \\
\hline
\end{tabular}

Source: Primary questionnaire data (2019)

According to table 1 , more than half of the informants $59.2 \%$ (154) were male while nearly fifty percent $40.8 \%$ (106) were females. Likewise, majority of the informants $71.2 \%$ (185) were students, signifying a good representation of key study informants for this study. Additionally, majority of the informants $42.8 \%$ (107) were aged 21 to 30 years, while more than a quarter $33.6 \%$ (84) were aged less than 20 years.

The results are agreeable with the percentage representation of different study informants in this study, with students who are the youngest comprising the highest percentage $71.2 \%$ (185), while instructors and Inst. leaders who were older comprised a quarter $25 \%$ (65) of the informants.

Further, informants of different working experiences also participated in this study, and the length of service was assumed to replicate into quality data about TVET advocacy strategies that promote gender equity of students.

Study informants further presented their level of qualification as shown in figure 2 .

Findings in figure 2 also showed that most informants had acquired formal education which acquainted them with relevant knowledge about strategies for promoting TVET advocacy and counteracting gender inequities in TVET.

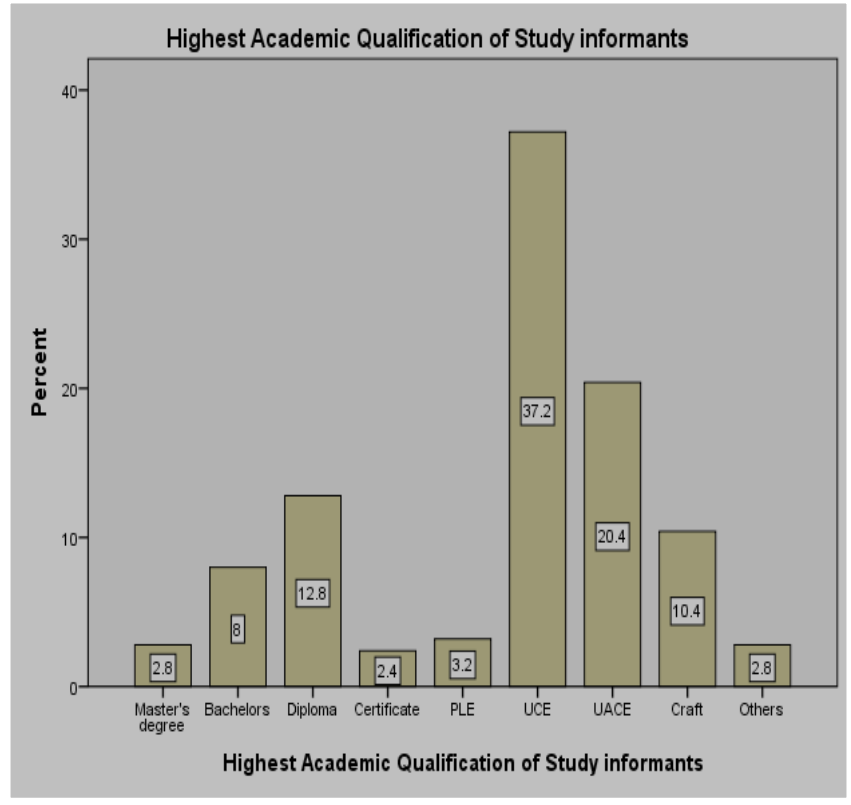

Figure 2: Informants' Academic Qualifications

\subsection{Students' Enrolment in Urban and Rural TVET Institutes}

To achieve this objective, institutional leaders provided information about their current students' enrolment basing on gender and TVET trades sampled for this study as shown in tables 2 and 3 .

\subsection{1: Current Students' Enrolment}

Table 2: Means and Standard Deviations for Students' Enrolment in Rural and Urban TVET Institutes

\begin{tabular}{|c|c|c|c|c|c|c|}
\hline \multirow{2}{*}{ Setting } & \multirow{2}{*}{$\mathrm{N}$} & \multirow{2}{*}{ Mean } & SD & $\begin{array}{c}\text { SD. } \\
\text { Error }\end{array}$ & \multicolumn{2}{|c|}{$\begin{array}{c}\text { 95\% Confidence } \\
\text { interval for mean }\end{array}$} \\
\cline { 4 - 8 } & & & & $\begin{array}{c}\text { Lower } \\
\text { bound }\end{array}$ & $\begin{array}{c}\text { Upper } \\
\text { bound }\end{array}$ \\
\hline Rural & 5 & 83 & 41.3 & 18.5 & 32.1 & 134.66 \\
\hline Urban & 4 & 364 & 57.4 & 28.7 & 272.1 & 454.9 \\
\hline Total & 9 & 207.9 & 154 & 51.5 & 89.1 & 326.7 \\
\hline
\end{tabular}

Results showed that the mean enrolment of students in urban institutions was close to five times (364) that in rural institutions (83). Additionally, the standard deviation ranged between 41-57, thus not clustered around the mean.

These results exhibited a major disparity in the enrolment of students in the two settings due to societal, economic, institutional, advocacy, and student-related factors. Likewise, interviews with key informants affirmed these reflections. One institutional leader noted:

We cannot take on female students without hostel facilities because some students come from far... (Mr. Owino, male Inst. leader, KNVI004, August 2019).

Likewise, another institutional leader said: 
We need money. Whenever students show interest in joining our programs, we do not hesitate to enrol them... (Mr. Odeke, male Inst. leader, August 2019).

Similarly, one CSO gender advocate noted:

Girls need a conducive environment that can entice them to stay in school. TVET institutions need to have attractive and spacious hostels, very clean toilets, and safe running water to make them feel at home.... (Ms. Pesi, female CSO advocate, July 2019).

The findings and excerpts affirmed multiple contributors to TVET advocacy which impact equitable participation of students in TVET. The findings concurred with studies by International Labour Organisation (ILO, 2016) in Lao which showed that the rural-urban divide impacted TVET participation. Thus, the percentage proportions of TVET participants were less than $5 \%$ in urban areas, $2.2 \%$ in rural areas with roads, and $1.3 \%$ in rural areas without roads. Similarly, Jones (2011) noted that school location stalled school access especially for girls in Uganda while Ayonmike, Okwelle, \& Okeke (2015) cited that lack of adequate classroom blocks, conducive staff offices, adequate electricity, water supply, TVET tools, machines and instructional materials affected quality participation in TVET. According to this, improving such facilities as a form of advocacy would encourage more students to enrol and participate in TVET, thus promoting gender equity.

\subsection{2: Trade-based Enrolment in TVET}

Institutional leaders further availed data about enrolment of female and male students in six different trades that were sampled for this study. The trades were: woodwork Technology (WWT), building and construction (BCP), Nursing, tailoring and garment design (TGD), agriculture and health Sciences (AHS), and electricity. Results are presented in table 3 .

Table 3: Percentages and Means for Trade-based Enrolment

\begin{tabular}{|c|c|c|c|c|}
\hline \multirow{2}{*}{ Trades } & \multicolumn{2}{|c|}{ Percentages (\%) } & \multicolumn{2}{c|}{$\begin{array}{c}\text { Mean } \\
\text { Enrolment }\end{array}$} \\
\cline { 1 - 3 } & Female & Male & \multicolumn{2}{c|}{} \\
\cline { 4 - 5 } & & & Female & Male \\
\hline WWT & $3(3 \%)$ & $99(97 \%)$ & 0.33 & 11 \\
\hline BCP & $32(10 \%)$ & $285(90 \%)$ & 4 & 32 \\
\hline Nursing & $176(59 \%)$ & $124(41 \%)$ & 20 & 14 \\
\hline TGD & $104(96 \%)$ & $04(4 \%)$ & 12 & 0.4 \\
\hline AHS & $21(53 \%)$ & $19(48 \%)$ & 2.3 & 2.1 \\
\hline Electricity & $49(10 \%)$ & $430(90 \%)$ & 5.4 & 47.7 \\
\hline
\end{tabular}

Source: Primary questionnaire data (2019)

Results showed that enrolment of females was nearly ten times $96.2 \%$ (104) that of males $3.8 \%$ (4) in TGD, a traditional gender stereo-typed TVET trade. Conversely, the representation of females in programs of WWT, BCP, and electricity was nearly a tenth $7.8 \%$ (28) compared to that of males $92.3 \%$ (271). Interestingly, the mean enrolment of females $55.6 \%$ (99) and males $44.4 \%$ (72) in Nursing and AHS was near parity for both genders. These findings implied that the varieties of TVET trades in institutions influenced gender-based enrolment and promoted stereotypes. One male gender advocate cited that:

Lately, the economic empowerment of girls and boys through acquiring hands-on skills is a major focus, especially those that have dropped out of school. Therefore, girls are equipped with tailoring and hairdressing skills while boys are equipped with knowledge of mechanics, metal and craft, motor-bike repairs... (Mr. Bagom, male CSO advocate, interview data, August 2019).

Whereas FST argued girls to have the same potential as boys for performing well in science and maths-based subjects (Thompson, 2003, p.7), the results portrayed gender stereotypes relating to participation in some TVET trades, thus leading to the noted gender inequities. These findings concur with studies by Mbirianjau (2009) and Kushmakar (2016), who reported a correlation between female and male students' enrolment in TVET institutions and the range of courses offered in the institutions. Thus, the more femaleoriented courses offered in an institute, the higher the number of females enrolled and vice-versa.

The researcher's interviews with students revealed more determinants for their choice of TVET trades. At KNVI004, a female student of electricity said:

My aunt who was working with Electricity Regulatory Authority encouraged me to join the Electricity course (Ms. Akol, female student, interview data, September 2019).

At LBAC005, a male student of TGD emphasized:

Our instructor madam Liya. motivates us. She tells us not to lose morale and she is the one who made me stay in this school. (Oumol, male student, interview data, October 2019).

These excerpts suggested that role models in TVET institutions and society enhance the equitable participation of both female and male students. The role models influence students to enrol in traditionally gender-stereotyped programs, and in their absence, the situation would be different. These results partly disagreed with those of Ngugi \& Muthima (2017) who noted that role models positively contributed to the participation of females in TVET but not both females and males.

\subsection{Knowledge of TVET Policies.}

The study sought for informants' familiarity with TVET policies as a form of TVET advocacy. Their views are presented in table 4 . 
Table 4: Familiarity with TVET policies

\begin{tabular}{|c|c|c|c|}
\hline TVET Policies & & Frequency & $\begin{array}{c}\text { Percentage } \\
\mathrm{s}(\%)\end{array}$ \\
\hline \multirow{4}{*}{$\begin{array}{c}\text { BTVET } \\
\text { strategic plan }\end{array}$} & Yes & 139 & 55.6 \\
\cline { 2 - 4 } & No & 111 & 44.4 \\
\cline { 2 - 4 } & Total & 250 & 100.0 \\
\hline \multirow{3}{*}{$\begin{array}{c}\text { NSGE in } \\
\text { Uganda }\end{array}$} & Yes & 111 & 44.4 \\
\cline { 2 - 4 } & No & 139 & 55.6 \\
\cline { 2 - 4 } & Total & 250 & 100.0 \\
\hline \multirow{3}{*}{$\begin{array}{c}\text { Other TVET } \\
\text { policies }\end{array}$} & Yes & 16 & 6.6 \\
\cline { 2 - 4 } & NO & 234 & 93.4 \\
\cline { 2 - 4 } & Total & 250 & 100 \\
\hline
\end{tabular}

Source: Primary questionnaire data (2019)

From the results, more than half of the informants $55.6 \%$ (139) were familiar with BTVET strategic plan while almost half of them $44.4 \%$ (111) were familiar with NSGE policy. Interestingly, some informants $6.6 \%$ (16) were familiar with other TVET policies including, the promotion of girl child education and prevention of gender-based violence (GBV).

Likewise, the researcher's interviews with students, district leaders, and ministry officials showed mixed perceptions about their knowledge of TVET policies. At MMNS006, a male student noted:

I do not know any documents written by either the institution, nursing society, or the government to encourage both male and female students to enrol in nursing (Luket, male student, interview data, October 2019).

Similarly, a female district leader cited:

.. I haven't seen any policy that focuses on technical training. What has been done in technical schools is the introduction of new courses that favour females or girls unlike in the past where there was no training... (Ms. Abinu, interview data, August 2019).

Contrary, a female ministry official elucidated:

Every department in the ministry has a guiding policy and they are numerous.... (Ms. Feni, lady Official, MoGLSD, September 2019).

These findings suggested average popularity of TVET policies, with a lag in information flow about TVET policies as corrective and affirmative strategies, from enacting bodies to implementers (Thompson, 2003). This information lag deters advocacy for TVET in terms of policy dissemination and implementation, which impacts the gender equity of TVET students. Policy dissemination and implementation would positively impact gender equity. These findings agreed with those by Pirzada (2020) which showed average utilisation of UNESCO TVET strategies by respondents in training and believed that gender equity and equality were useful TVET strategies in their institutions.

\subsection{Use of Different TVET Advocacy Strategies}

Informants' views were sought about the extent of using different TVET advocacy strategies with a four-point Likert scale with numerical values of 4, 3, 2, and 1 for always, often, sometimes, and never respectively. The means of their views are presented in table 5 .

Table 5: Mean and Standard Deviation for Use of TVET Advocacy Strategies

\begin{tabular}{|c|c|c|c|}
\hline Advocacy Strategies & Mean & SD & Remarks \\
\hline Career guidance & 3.30 & .797 & Often used \\
\hline $\begin{array}{c}\text { Research and } \\
\text { publication }\end{array}$ & 2.76 & .963 & Often used \\
\hline Public Lectures & 2.74 & 1.027 & Often used \\
\hline Fliers and magazines & 2.28 & 1.042 & sometimes \\
\hline Social media & 2.98 & 1.044 & Often used \\
\hline $\begin{array}{c}\text { TVET and Gender } \\
\text { policies }\end{array}$ & 2.67 & 1.039 & Often used \\
\hline N of Valid cases & \multicolumn{3}{|c}{250} \\
\hline
\end{tabular}

SD- standard deviation

Source: Primary questionnaire data (2019)

Except for fliers and magazines, the results showed that respondents agreed to often have used the different advocacy strategies based on mean ranges 2.67 to 3.3. The standard deviation indices ranged from 0.8 to 1.04 , implying that informants' responses were clustered around their means.

Triangulating with interview data for some informants, they cited that:

Through advertising, we girls at the foundation level have known that we can upgrade and become civil engineers in the future... (Ms. Atipo, female student, interview data, September 2019).

One male district leader also highlighted:

To improve enrolment, we have done advertisements through mass media and in churches because most of our TVET institutes are church-based.......(Mr. Mumiso, male DL, Interview data, August 2019).

According to a female gender advocate from CSO, she noted:

Looking at the constitution, we together with other organizations ensured that our constitution is gender-sensitive and promotes equal opportunities for all genders. We collaborate closely with MoGLSD, the parliamentary committee on gender, and over 20 CSO..... (Ms. Yadak, female advocate, interview data, September 2019).

However, the researcher's observation of the learning environment for TVET advocacy messages revealed that none of the six TVET institutes had gender advocacy messages within classrooms, sanitation areas, dormitories, and 
compounds. Likewise, the majority lacked functional gender units.

These findings affirmed the use of some advocacy strategies like career guidance, research, and sensitisation unlike others like the use of posters or fliers. The use of these strategies would boost sensitization and information flow about TVET, thus encouraging more students to participate therein. These findings corroborated with studies by Atkins \& Flint (2015); Muthima and Ngugi (2017); and Olelewe, et al., (2019) which commended the use of multiple advocacy strategies for enhancing participation in TVET. Failure to use these strategies would hamper equitable participation (Cheruiyot \& Wanyaga, 2019).

\subsection{Perceptions about Advocacy Strategies that Enhance Gender Equity}

Using a five-point Likert scale with numerical values of 5, 4, 3, 2, and 1 for Strongly Agree (SA), Agree (A), Undecided (UD), Disagree (DA), and Strongly Disagree (SD), the study also sought for informants' perceptions about how different advocacy strategies can promote gender equity in TVET programs. Their views are shown in table 6 .

Table 6: Means for Advocacy Strategies that Promote Gender Equity

\begin{tabular}{|c|c|c|c|c|}
\hline S/N & TVET Advocacy Strategy & Mean & SD & Remarks \\
\hline 1 & $\begin{array}{c}\text { Enactment of TVET and gender } \\
\text { policies }\end{array}$ & 4.24 & .94 & Agree \\
\hline 2 & $\begin{array}{c}\text { Increasing sensitization for gender } \\
\text { issues in institutions }\end{array}$ & 4.66 & .62 & Agree \\
\hline 3 & $\begin{array}{c}\text { Fair treatment of girls and boys in } \\
\text { TVET }\end{array}$ & 4.25 & 1.15 & Agree \\
\hline 4 & Increasing sensitization for TVET & 4.64 & .70 & Agree \\
\hline 5 & Research in TVET & 3.89 & .94 & Agree \\
\hline 6 & $\begin{array}{c}\text { Involvement of institutional and } \\
\text { community leaders }\end{array}$ & 4.36 & .83 & Agree \\
\hline 8 & $\begin{array}{c}\text { Implementation and evaluation of } \\
\text { TVET policies }\end{array}$ & 4.17 & .80 & Agree \\
\hline 9 & Government and Political will & 4.14 & 1.07 & Agree \\
\hline 10 & $\begin{array}{c}\text { Improving parents' attitude towards } \\
\text { TVET }\end{array}$ & 3.98 & 1.16 & Agree \\
\hline 11 & $\begin{array}{c}\text { Boosting students' attitude towards } \\
\text { TVET }\end{array}$ & 3.98 & 1.14 & Agree \\
\hline 12 & $\begin{array}{c}\text { Involvement of male instructors } \\
\text { and role models in TVET }\end{array}$ & 3.41 & 1.36 & Disagree \\
\hline & Number of Valid cases & 250 & \\
\hline
\end{tabular}

\section{SD- Standard deviation}

Source: Primary questionnaire data (2019)

According to the results, respondents rated eleven items (111) as advocacy strategies that enhance gender equity, while they disagreed with one strategy (item 12). The SD indices ranging between 0.6 and 1.36 showed that informants' responses were clustered close to their means.

Additionally, interviews with key informants cited TVET advocacy strategies that promote gender equity. An advocate from CSO emphasized that:
.... affirmative action has seen many disadvantaged women and girls access education and occupy leadership positions. Alliances with the socialcultural leaders to support and promote the rights of women and girls are key. We have also brought men on board to become champions of girls' education and gender equity. We influenced the MoGLSD to come up with the male engagement strategy to ensure that the men in top decisionmaking positions are gender-sensitive (Ms. Yadak, female advocate, interview data, October 2019).

Similarly, a female role-model instructor at WKTI003 affirmed that:

TVET policies contribute to students' enrolment because the BCP first-year class has more girls admitted than year two class due to sensitization. When these policies are developed and people talk about them, students are informed... When parents find girls enrolled in TVET courses, they are motivated to bring their daughters (Ms. Harito, female instructor, interview data, August 2019).

These findings and excerpts showed that TVET advocacy in form of affirmative policies, community and cultural leader alliances, male-engagement strategy, TVET policies and sensitization about TVET and gender policies enhance gender equity. The findings concurred with Ayonmike, et al., (2015) who commended adequate planning and implementation of TVET programs by the government as a strategy for attaining quality TVET participation. Ngugi \& Muthima (2017) encouraged support for fair and equal opportunities for girls and women in TVET fields of study, as a form of advocacy. Results disregarded recommendations of NSGE about embracing male involvement in supporting girls' education, male role-models at community levels, father-protectdaughter campaigns, and including boys in gender-responsive activities in education institutions (MoES, 2013). Results further disagreed with studies by Ngugi \& Muthima (2017) which suggested that female or male role-models in female or male-oriented TVET programs promote gender equity.

\section{CONCLUSIONS}

Based on the results, it is imperative to conclude that the effective use of multiple TVET advocacy strategies positively impacts gender equity in TVET. Multi-sector collaborations for TVET advocacy enhance equitable participation. Attitude changes for TVET and gender issues culminate into positive TVET advocacy. More so, advocacy for TVET and gender policies requires government and political will, as well as a conducive learning environment. However, the involvement of male instructors and role models to champion gender equity campaigns does not contribute to the gender equity of students. 


\section{RECOMMENDATIONS}

The study recommended that:

1. TVET advocacy strategies should be effectively implemented in all institutions in Uganda.

2. The government should employ experts for TVET advocacy in the different institutions, ministries, and other stakeholders to support its mandate for TVET and gender policies.

3. The government needs to increase budgeting for the dissemination and implementation of strategies for TVET advocacy.

4. More research needs to be conducted in other regions of Uganda about TVET advocacy, in a bid to improve the status-quo of TVET.

5. The MoES needs to diversify evaluations for the contribution of different TVET and gender policies to gender equity in the different regions of the country.

\section{REFERENCES}

[1] Adelakun, O. A., Oviawe, J. I., \& Barfa, G. I. (2015). Strategies for Enhancing Females' Participation in Technical, Vocational Education and Training (TVET) in Nigeria. Advances in Social Sciences Research Journal, 2(4), 110-120.

[2] Atari, O. D., \& Mckague, K. (2015). South Sudan: Stakeholder's views of Technical and Vocational Education and Training and a framework for action. Journal of Vocational education and training, 169-186.

[3] Atkins, L., \& Flint, K. J. (2015). Nothing changes: Perceptions of vocational education in England. International Journal of Training Research, 13(1), 35-48.

[4] Ayonmike, C. S., Okwelle, P. C., \& Okeke, B. C. (2015). Towards Quality Technical Vocational Education and Training (Tvet) Programmes in Nigeria. Journal of Education and Learning, 2534.

[5] Cheruiyot, S. K., \& Wanyaga, F. M. (2019). Gender Inclusion in TVET: An Examination of Sustainable Interventions in Selected TVET Institutions in Kenya's Sustainable Development in Education. International Journal of Science, Technology, Education and Management Research, 4(3), 39-55.

[6] Cohen, L., Manion, L., \& Morrison, K. (2011). Research Methods in Education (7th Edition). New York: Routledge.

[7] Creswell, W. J. (2014). Research Design; Qualitative, Quantitative \& Mixed Approaches (4th Edition). Thousand Oaks, California: Sage Publications.

[8] Eccles, J. (2005). Gender Achievements and Motivation. Retrieved from https://en.wikipedia.org/wiki/Expectancyvalue theory\#Subjective task values.

[9] Gore, J., Ellis, H., Fray, L., Smith, M., Lloyd, A., Berrigan, C., . . Holmes, K. (2017). Choosing VET: Investigating the VET Aspirations of School Students. Adelaide, Australia: National Centre for Vocational Education Research.

[10] ILO. (2016). Compilation of Assessment Studies on Technical Vocational Education and Training (TVET): Lao People's
Republic, Mongolia, The Philippines, Thailand, and Vietnam. Bangkok: International Labour Organisation.

[11] Jones, S. K. (2011). Girls Secondary Education in Uganda: Assessing Policy within the Women's Empowerment Framework. Gender and Education, 23(4), 285-413.

[12] Kell, P. (2010). VET Shifting Responses to Inequality, Disadvantage, and Equity. International Journal of Training Research, 2(8), 98-102.

[13] Kushmakar, B. (2016, July). Gender Equality and Social Inclusion in Vocational Education and Training. Journal of Advanced Academic Research, 3(11), 29-39.

[14] Mbirianjau, W. L. (2009). Access to and Participation of Women in Science-oriented Vocation Education and Training. Nairobi: Kenyatta University Unpublished Masters' Thesis.

[15] Ministry of Education and Sports (MoES). (2013). National Strategy for Girls' Education in Uganda (2015-2019). Kampala, Uganda.

[16] Mjelde, L. (2007). The Magical Properties of Workshop Learning. Bern: Peter Lang.

[17] MoES. (2011). Skilling Uganda: BTVET Strategic Plan 2012/132021/2. Kampala, Uganda: Ministry of Education and Sports

[18] Mugenda, O., Kimani, E. N., Maina, L. W., \& Wainaina, M. (2010). Female Representation at Various Levels of Education in Kenya: Identifying Opportunities for Policy, Actions, and Linkages. Nairobi: Longhorn Publishers.

[19] Ngugi, M., \& Muthima, P. (2017). Female Participation in Technical, Vocational Education and Training (TVET) Subsector; The Kenyan Experience. Public Policy and Administration Research, 7(4), 9-23.

[20] Okello, B. (2012). Factors Influencing the Attitude Towards Technical Vocational Education and Training in Uganda. Nairobi: Kenyatta University, Unpublished $\mathrm{PhD}$ Thesis.

[21] Olelewe, J. C., Orji, T. C., Onisen, E. C., \& Ikemelu, R.-K. C. (2019). Constraints and Strategies for Effective Use of Social Networking Sites (SNSs) for Collaborative Learning in Tertiary Institutions in Nigeria: Perceptions of TVET Lecturers. Education and Information Technologies, 25, 239-258

[22] Pirzada, G. (2020, July 20). Effect of including global TVET worldview in TIMT (TVET Institute Management Training) on Vocational Institute Management in Pakistan.

[23] The Republic of Uganda. (1995). Constitution of the Republic of Uganda. Kampala, Uganda

[24] Thompson, A. (2003). Caring in Context: Four Feminist Theories on Gender and Education. Curriculum Inquiry, 33(1), 9-65.

[25] UBOS. (2012). 2012 Statistical Abstract. Kampala, Uganda.

[26] UBOS. (2016). 2016 Statistical Abstract. Kampala, Uganda

[27] UNESCO. (2016a). Education for People and Planet: Creating Sustainable Futures for All. Paris: UNESCO.

[28] UNESCO. (2016b). Strategy for Technical Vocational Education and Training (2016-2021. Paris, France: UNESCO.

[29] United Nations. (2015). Transforming our world: The 2030 Agenda for Sustainable Development P. L. No. A/RES/70/1

[30] United Nations Girls' Education Initiative. (2012). Gender Analysis in Education. New York: UNGEI.

[31] Wheelahan, L., \& Moddie, G. (2016, November). Global Trends in TVET: A Framework for Social Justice. Brussels, Belgium.

[32] World Economic Forum (WEF). (2019). Global Gender Gap Report 2020. Geneva: World Economic Forum. 